\title{
Sidney S. Harcave, 1916-2008
}

Sidney S. Harcave died on 24 October 2008 in Johnson City, New York, at the age of 92. Born in Washington, D.C., on 12 September 1916, Harcave earned his B.A. from the City College of New York. Following the advice to "do something different in graduate school," he began studying Russian history under Samuel Harper at the University of Chicago. When he received his doctorate in 1943, Harcave was among the earliest generation of American-trained Russian historians. After graduation, he worked as a foreign area specialist for the Foreign Broadcast Intelligence Service and as an analyst at the Office of Strategic Services (OSS) and the State Department. After World War II, he began his teaching career at the University of Wyoming and Champlain College. In 1953, Harcave joined the faculty at the State University of New York, Binghamton, where he remained until his retirement in 1982.

Research was important to Harcave from the start of his career. In 1950-1951, he was a participant in the Harvard Refugee Interview Project, which gave western specialists an important early look inside the Soviet system. Based largely on material gathered from these interviews, Harcave published Structure and Functioning of the Lower Party Organizations in the Soviet Union (1954). In 1952, he responded to the growing interest in the Soviet Union that accompanied the birth of the Cold War with his Russia, A History. This college textbook was quite popular and ultimately went through six editions, the last appearing in 1968. In the two-volume Readings in Russian History, edited in 1962 and reprinted several times, Harcave also sought to make primary sources more easily accessible. His monographs include First Blood: The Russian Revolution of 1905 (1964) and Years of the Golden Cockrel: The Last Romanov Tsars, 1814-1917 (1968). Harcave's scholarly work continued well after his retirement. He edited and translated Memoirs of Count Witte (1990) and followed this up with the biography Count Sergei Witte and the Twilight of Imperial Russia (2004). At the time of his death, he was actively engaged in writing his own memoirs.

Even with all his research and publications, Harcave was able to devote time and attention to generations of students. His broad knowledge meant that his classes were both interesting and challenging. Harcave's generosity with his graduate students knew few bounds.

The field has indeed suffered a loss with Harcave's passing. He was predeceased by his wife Nora in 1997 and is survived by a cousin. Known for his commitment to research and high standards, Harcave will be missed by students and colleagues alike.

Mark Kulikowski

State University of New York, Oswego March 2009 